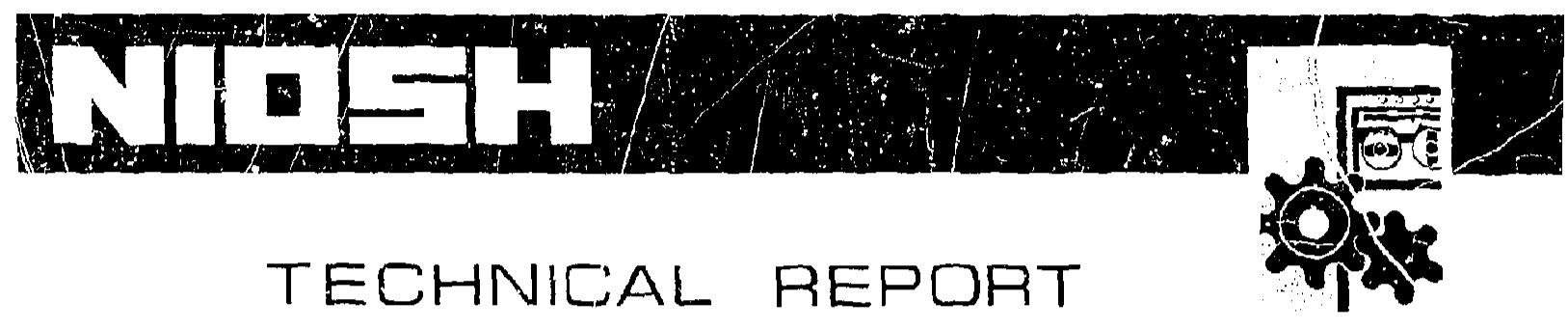

\title{
CONTROL TECHNOLOGY FOR WORKER EXPOSURE TO COKE OVEN EMISSIONS
}



PERSONNEL SEFrivices

\section{Zlinited \\ (USS) States \\ Steel \\ Corporation}

BOO GRANT STREET
PITTSBUSGH, PENASYLVANIA 15230

Decerber 18, 2978

Mi:- John W. Sheehy

Chemical Engineer

Cherical Afrents Control Section

Departinent of Health, Education,

- and Welfare

467 Columbia Parkway

Cincinnati, ohto 45226

Dear Mr. Sheehy:

You have our permission to use Figures $4-5,4-14$, and 4-24 as requested in your Derember 8 , 1978 letter.

Please accompany each Figure with the "Copyright 1971 by United states steel corporation" notice.

Yours cruly,

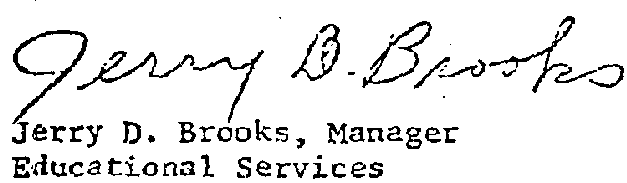

HDB: atg

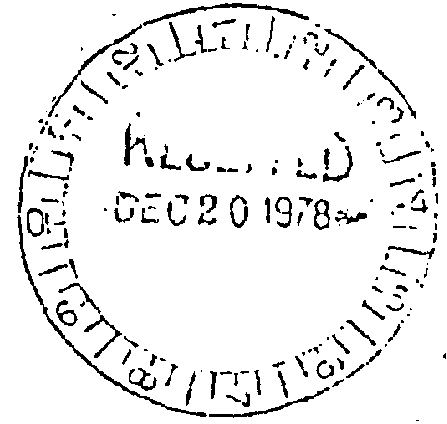




\section{MAY 291980}

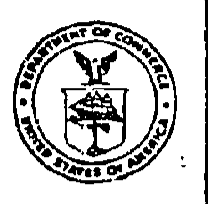

\section{UNITED STRTES DEPARTMENT OF COMMERCE Mational Technical information Service 5285 Port Hoyal Road Springfiedd, V'irginia 22161}

U133098

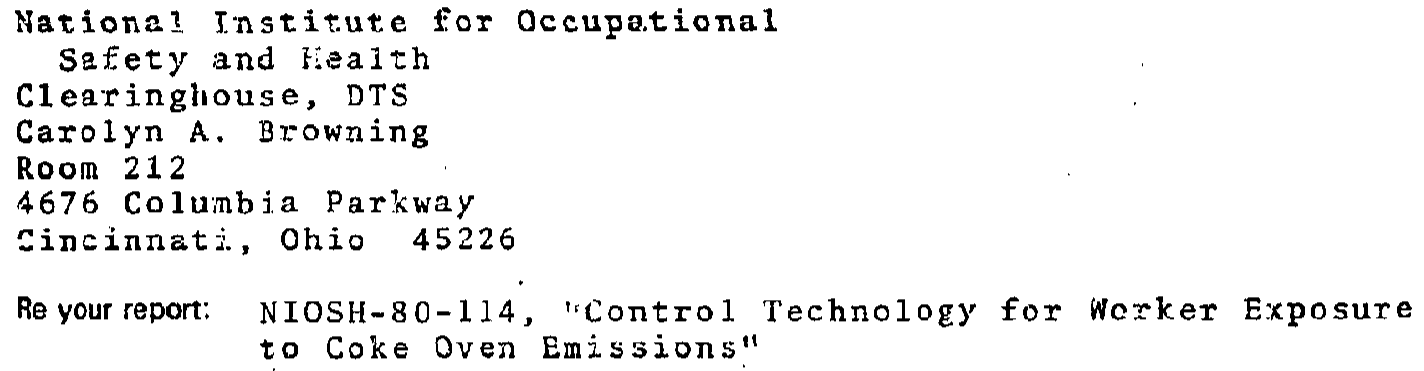

We are not able to process your report for the following reasons. Please make the corrections necessary and return the document and th is letter to us. Report format is to conform with tile ANSI standard, ANSI Z39.18, entitled "Format and Production for Scienrific and Technical Reports" available @ $\$ 4.00$ from the American National Standards Institute, Inc., 1430 Broadway. New York, New York 10018.

1. Pages are missing.

2. All pages are not numbered and some could therefole be missing. We suggest author or editor number the pages consecutively throughout the document, or within chapters if prefixed by the chapter designation.

3. Some pages are not reproducible.

4. A Report Documentation Page (RDP) must accompany each titie. Blank forms are enclosed.

5. This document has copyright or other restrictions. Please furnish written authorization for NT/s to reproduce and sell to the public. Copyright - Pgs 4, 6 \&?

6. An Accession Notice Card must accompany each title. Blank forms are enclosect.

7. We cannot microfiche pages la. ger than the standard $8 \% \times 11$ in one frame (see ANSI standaid). Please reduce pages exceeding $8 \frac{1}{2} \times 11$ in this document before returning and limit the page size of future clocuments to standard size.

8.

Sincerẹlv,

Shicerelv,

JOHN H ASHLEY

Input Branch

Phone: 703-557-4690

FSC/rkb

Form NTIS-63 (Rev 3.78) 
CONTROL TECHNOLOGY FOR WOKKER EXPOSURE

TO COKE OVEN EMISSTOHS

John W. Sheehy

U.S. DEPARTMEN'T OF GEALTH, EDUCATION, AND WELFARE Public Health Service

Center for Disease Control

National Institute for Occupational Safety and Health

Division of Physical Sciences and Engineering

Cincinnati, Ohio 45226

March 1980

For snle by the Superintesdent of Documents, U.S. Goverrment

PrInting Office, Washingt on, D.C. 20402 


\section{DISCLAIMER}

Mention of company names or products does not constitute endorsement by the National Institute for Occupational Safety and Health

DHEW (NIOSH, Publication No. 80 - 114 


\section{ABSTRACT}

Numerous studies have shown "coal tar" prooucts increase the risk of skin and lung cancer. One study showed top side coke oven workers had a lung mortality rate 10 times that of all. steel workers. Another study showed that men employed at coke ovens for more than five years showed a mortality rate 3.5 times the expected rate. In view of this significant bealth hazard to thousands of coke oven workers a NIOSH in-house study to assess coke oven rontrol technology was performed.

Control technology for coke ovens was assessed through visits to seven United States coke oven plants with state-of-the-art control technology and by a review of current coke oven control tachnology iiterature. Each control method is briefly described and the effectiveness of important engineering and work practice controls is presented. The report discusses, separately, controls for charging emissions, pusining emissions, door emissions, and top side leaks.

Charging emission controls include larry car stage charging, fixed duct secondary collectors, and pipeline charging. More than a dozen pushing emission control methods are discussed in the report. Door emissions control technology such as new docr sealing techniques, guillotine doors and exhaust hoods are described anó evaluated, and enclosed filtered air systens are discussed.

Significant conciusions are: Greater effort should be devoted to the development of control technology for door emissions, and pipeline charging appears to have advantages over larry car stage charging in reducing worker exposure. Important recommendations include: Develop cantrols for 6-meter metal-to-metal doors, evaluate well ventilated sheás, and evaluate pipeline charging in terms of worker exposure. 
CONTENTS

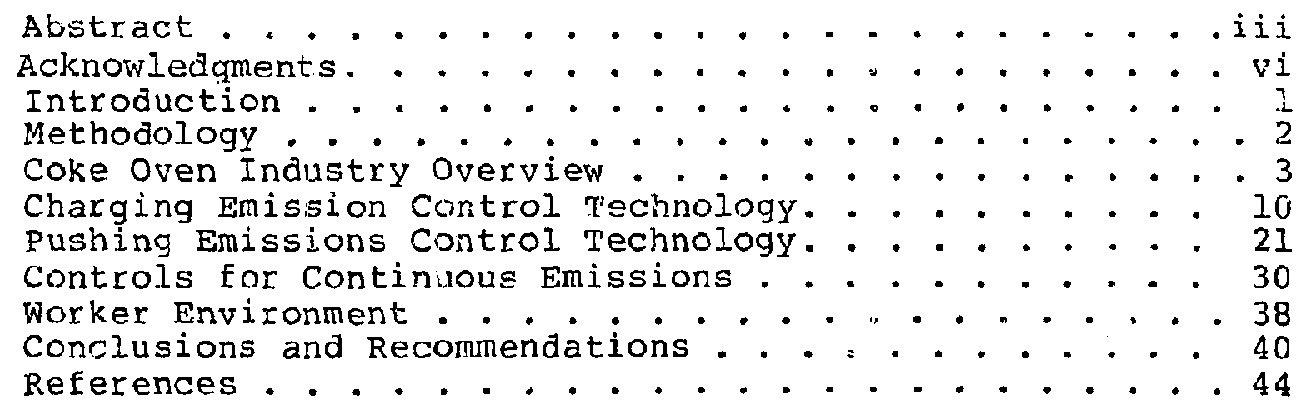




\section{ACKNOWLEDGMENTS}

We wish to thank the steel comparies and merchant coke plants for their cooperation and assistance in this study. We also wish to thank Mr. Andrew Trenholm, Envi.ronmental protection Agency, Mr. John Barker, Armco Steel, and Messrs. Dennis D'Brien, Jercine Flesch, and Robert Hughes, NIOSH, who provided technical guidance in the preparation of this manuscript. 


\title{
INTRODUCTION
}

\begin{abstract}
Numerous studies have shown the use of "coal tar" products increases the risk of skin and lung cancer. One study showed top side coke oven workers employed for more than 5 years had a lung mortality rate 10 times that of all steel workers. Another study showed that men employed at coke ovens for more than 5 years showed a mortality rate 3.5 times the expected rate $(1)(\overline{2})$.
\end{abstract}

In view of the significant health hazards to thousands of coke oven workers, the NIOSli Control Technology Research Branch undertook a study to assess coke control technology. The results of the study are documented in this report.

The report summarizes coke oven control technology, including engineering controls and work practices, developed in the United States and in other countries. Each control method is briefly described and, if known, the current status of each contrul is described. This report discusses, separately, controls for charging emissions, pushing emissions, dcor emissions, and top side leaks. Enclosed filtered air cabs and pulpits are also described.

The information in the report was obtained through five visits to seven United States coke oven plants with stace-of-the-art control technology, and through a review of the current coke oven control technology literature. 


\section{METHODOLOGY}

Articles from the litarature as well as basic textbooks on coke oven constructior and operation have been reviewed. opinions from the united steel Workers, control equipment manufacturers, industrial health personnel, and approximately 40 coke plant operators were solicited for recommendations of candidate plants for study. plants were selected on the basis of the variety of control technigues in use, the degree of control, and the availability of existing sampling data.

One-to two-day surveys of sever coke plancs, including producers of both foundry and blast furnace coke, were conaucted to obtain general plant data (size, age, controls), to observe engineering and work practice control methods, and to review existing plant exposure data. This report discusses the information gathered during the surveys and Iiterature review. A wide range of engineering controls and work practices are identified, and effectiveness of these controls is discussed in the report. 


\section{COKE OVEN INDUSTRY OVERVIEW}

Metallurgical coke is made by the destructive distillation or carbonization of bituminous coal. The distillation is done by baking the coal in ovens to achieve a uniform "skin temperature" of 1900 to 20000 for 16 to 20 hours. The result of the distillation is a "cellular, porous compound which is heterogenous in both physical and chemical properties," known as coke $(3)$.

There are several uses for coke. About 92 percent of the coke is used as a reducing agent and fuel in the biast firrnaces in ferrous and nonferrous metals production. Five percent is used as a cupola fuel in foundry operations and three percent is used in other industries $\{4\}$.

The largest producer of coke in the united States is the steel industry with over 90 percent of total coke production. Eight percent is produced by foundry plants (4).

COKE OVEN DESCRIPTION

There are two main types of coke ovens: The beehive and the by-product. The scope of this study is limited to only by-proluct coke ovens, so a description of the beehive oven is cinicted.

As of 1974 , there were 65 by-product coke oven plants with a total of 13,490 ovens. The predominant design of these coke ovens are the Koppers, Koppers-Becker, and Willputte ovens whi ch constitute about 97 percent of all the by-product ovens. Figure I shows a simplified diagram of these ovens. As shown, the basic difference between the ovens is in the method of firing the ovens (3).

A single coise oven consists of a coking chanber and a heating chamber. The coking chamber is generally from 30 to 42.5 feet in length, from 6 to 20 feet in height, and 12 to 22 inches in width. A series of 1.0 to 100 coke ovens form a battery. In the batiery, the coking chambers are alternated with the heating chambers (3).

The coal is charged into the coking chambers from the top of the oven. The coal is charged by one of two methods: Larry cax or closed charging system. In a closed system, coal is conveyed directly into the chambers by pipeline or chain conveyor. Charging by larry car requires three steps: 1) coal is discharged into the hoppers on the larry car from a central bunker; 2) the larry car moves by rail to a position over the chamber to be charged; and 3) the coal is charged into the chamber from the lariy car. 

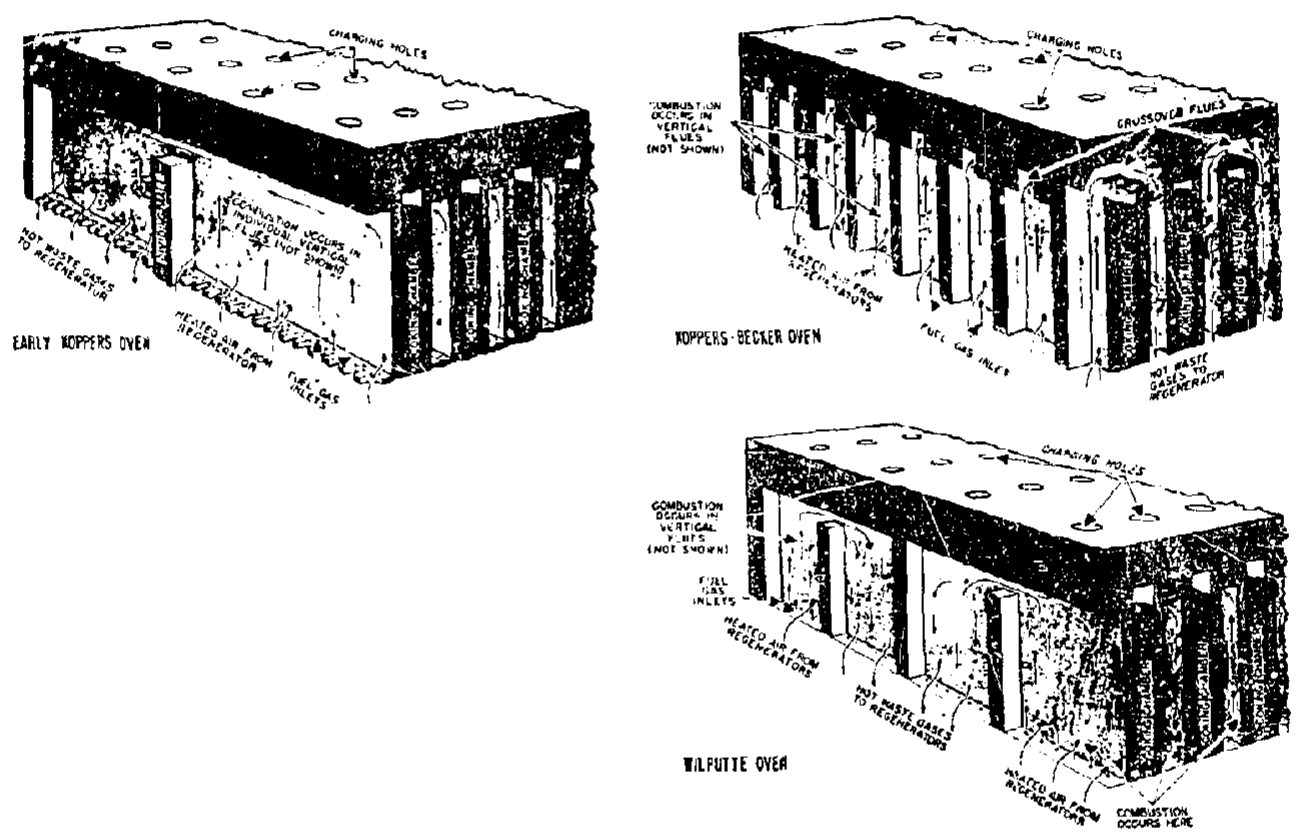

Figure 1. Schematic representation of the differences in firing methods employed in the three most common types of coke ovens. Individual flues are nat shown. The firing procedures shown are for a single phase of heating which is reversed at the end of a specified period. (Copyright 1977 by United States Steel

Corporation.) (User with permission) 
Except for preheated coal, the coal must be leveled in the coking chambers. This is accomplished by passing a leveler bar through a door on one side of the chamber across the top of the chamber as shown in Figure 2. Preheated coal is self-leveling.

The next step after charging and leveling is to seal the coking chamber. This is accomplished either by placing lias on the chamber charging holes and luting around the lids for larry car charging, or by closing a valve for pipeline charging.

In the coking process, by-products from the coking chamber are drawn off through a collection system consisting of horizontal collecting main (or mains) and a gooseneck standpipe. A typical system is shown in Figure 3 . In some cases the collection system is equipped with a stear aspiration system which is used to facild tute the withdrawal of by-products from the coking charber during charging and leveling.

Once the coal is coked, the doors on the sides of the coke oven are removed. A pusher machire (on the push side) operates a ram which pushes the coke through the oven to the coke side, as shown in Figure 2. The hot coke passes through a "coke guide" into a rail mounted guench car. The coke laden quench car moves to a "quench tower" where it is cooled with water. The quenchs car subsequently takes quenched coke to the coke wharf. At the battery, the doors are replaced and the oven is readied for the coal charging.

\section{EMISSIONS}

'The approximate amounts of by-products obtained by coining 1 ton of coal in the by-product process are:

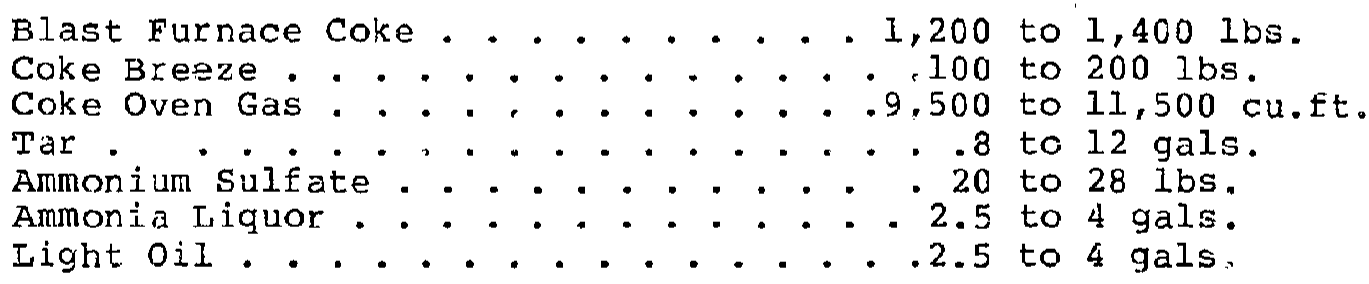

The coke oven gas consists of hydrogen, metrane, ethane, carbon monoxide, carbon dioxide, ethylena, propylene, butylene, acetylene, hydrogen sulfide, ammonia, oxygen, and nitrogen. The tar is the source of pyridine, tar acids, napthalene, creosote oil, and coal-tar pitch. Benzene, xylene, toluene, and solvent napthas are the components of the light oil(3).

The major emission sources on coke ovens include: Leaks around lids ald doors on the top and sides, charging emissions, pushing emissions, and emissions during gooserieck cleaning. 


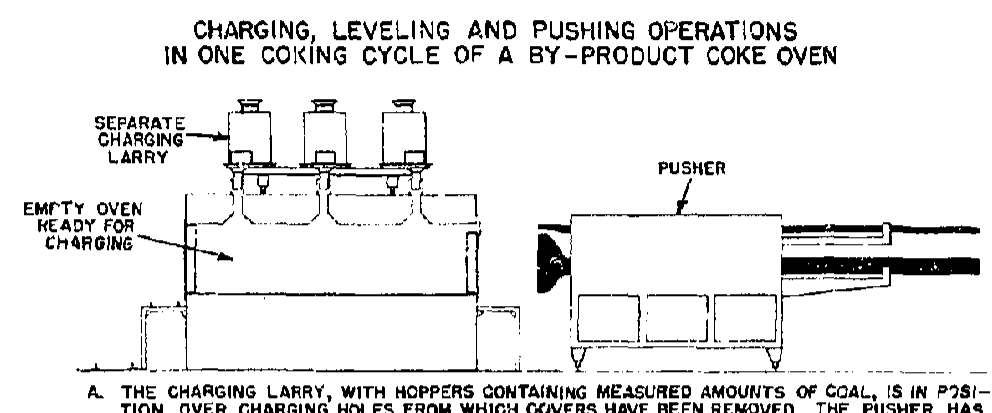

A. THE CHAAGING LARRY, WITH HOPPERS CONTAINING MEASURED AMOUNTS OF COAL, IS IN PZSIBEEN MOVEO INTO POSITION.

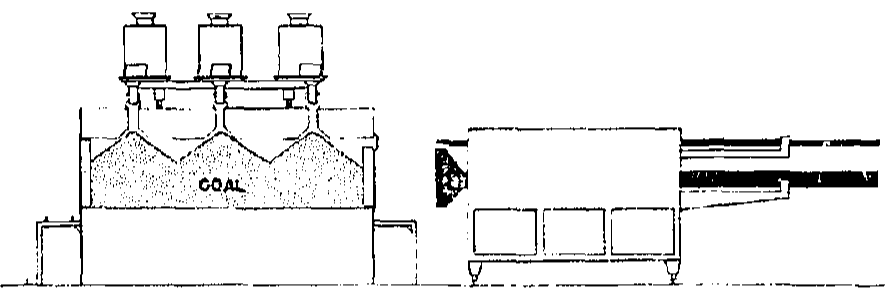

B THE COAL FROM THE LARRY HONPERS HAS JROPPED INTC THE OVEN CHAMBER, FORMING

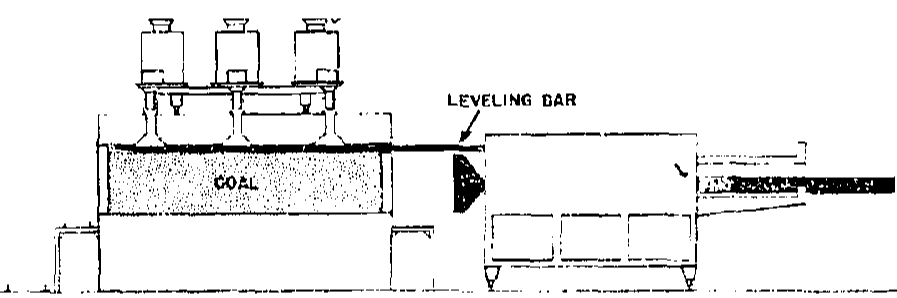

a THE LEVELING DOOS AT THE TOP OF THE OVEN DOOR ON THE TUSHER SIDE HAS BEEN OPENER AND THE LEVELING BAR ON THE PUSHER HAS BEEN MOVED BACK AND FORTH ACROSS THE PEAKED CCAL PILES TO LEVEL THEM. THE GAR NEXT IS WITHORAWN FROM THE OVEN, THE LEVELING DOOR AND CHARGINO HOLES ARE CLOSED, AND THE COK.NG OPERATION GEGINS.

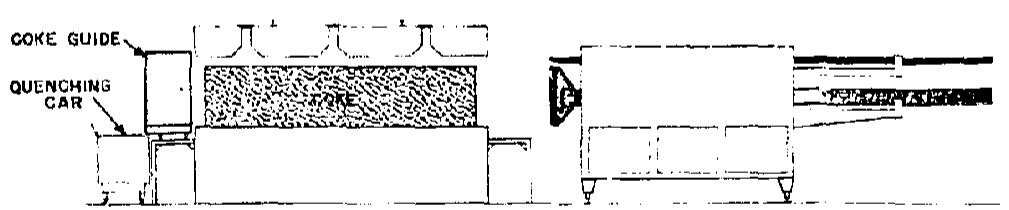

Q COKING OF THE GOAL JRIGINALLY GHARGED IN TO THE OVEN HAS BEEN COMPLETEO IN ABCUT 18 HOURS) AND THE OVEN IS SEAUY YO BE PUSHED. THE: OVEN DDOFS ARE REMOVED FROM EACH END. AND THE PUSHER, GOKE SUIDE AMD QUENGHING CAR AHE MOVER INTO FOSITION.

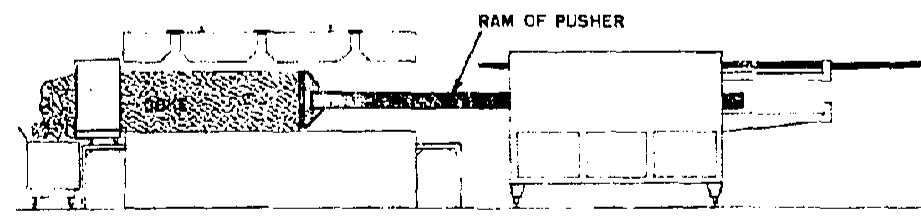

E. THE RAM OF THE PUSHER ADVANEES TO PUSH THE INCANDESCYNT COKE OUT OF THE OVEN, THROUGH THE GOKE GUIDE AND INTO THE OUENCHING GAR.

Figure 2. Schematic representation of the sequence of operations in charging, leveling, and pushing in one coking cycle of a by-product coke oven. (Copyriaht 1971 by United Steel Corporation.) (Used with permission) 


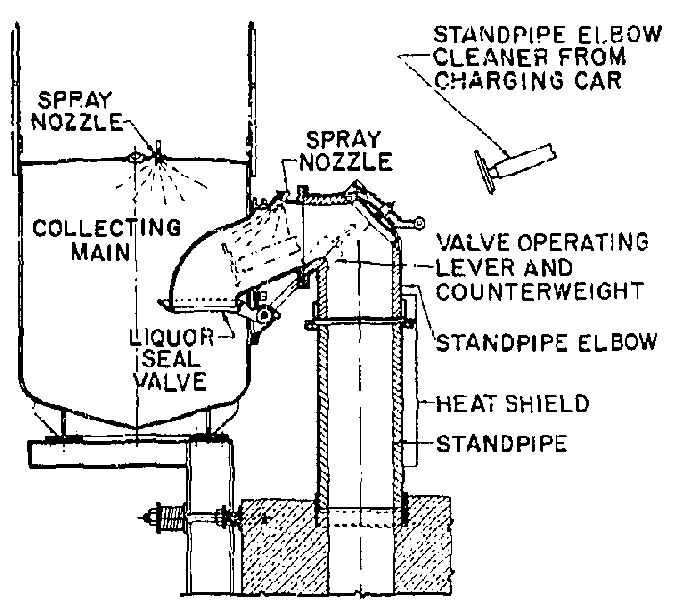

Figure 3. Wilputte arrangement of staridpipe, liquid sealed damper valve, and collecting main. (Courtesy, Wilputte Coke Oven Div., Allied Chenical Corp.) (Used with permission) 
CHARGING EMISSION CONTROL TECFINOLOGY

Barnes et al. reported that for a well operated coke plant in 1970, without special emission control equipment, charging emissions represented about 60 percent of total coke oven $\mathrm{p}^{1}$ an: emissions (5). Charging emissions have been greatly reduced in the $1770^{\prime} \mathrm{s}$, and no longer represent such a large portion of emissions. Even so, research and development continues in an effort to further reduce charging emissions. In this study, 1or 2-day surveys were made to seven coke oven plants. Charging emission control systems were observed at each of these plants. The major charging emissions control systems are presented in Table 1 .

Charging emissions result from the discharge of coal to coke ovens. As the coal is introduced into the hot coke oven, there is a suddon aisplacement of air along with some initial combustion of the Eresh coal. The resulting smoke and gases are forced out of tise oven through any opening or cracks. There are two primary methods of controlling smoke and gases: 2) prevent gases from escaping and 2) clean the gases before discharging them into the environment. Generally, there are two systems for challging ovens. Each system is discussed separately below.

\title{
LARRY CAR STAGE CHARGING
}

Two techniques for charging coal are larry car charging and closed

\section{LARRY CAR CHARGING}

\author{
Stage charging (operating technigue) \\ Stage Charging with Automatic Lid Openirg, \\ closing and Mudding \\ Larry Car Mounted Wet Scrubbers \\ Sequential Charging (operating technique) \\ AISI/EPA Car \\ Still-Erin Car \\ Fixed Duct Secondary Collectors
}

PREHEATED COAL CHAFGING SYSTEMS

Pipeline coal Charging

Conveyor Coal Charging

Simcar Two-stage Preheated Coal Dharging

Table 1. Charging Emissions Controls

charging systems. (In a closed system, coal is corveyed into the oven by pipeline or by chain conveyor.) Lacry car charging is the rost common method of charging coal into the oven. Control of emissions from larry car charging requires a 
combination of engineering and work practice controls. Larry car charging emission controls include: I) stage charging (or sequential charging), 2) double collection mains, 3) jumper pipes, 4) gooseneck cleaning, 5) nagh pressure aspiration and 6) scrubber larry car.

A number of control systems for larry car charging emissions were observed in the study. At a fully integrated steel. mill with a single coke oven battery, the coal is charged bj: a modified larry car equipped with an enclosed air conditioned cab, a screi feeder, a jumper pipe, and volumetric controls for regulating the amount of coal in each larry car hopper. A standpipe cleaner with expanding biades is located on the "bridge" of the larry car. The larry car operator operates the stand pipe cleaner from the "bridge." This eliminates a hazardous task normally performed by the lidman.

The coal is charged using the "stage charging" operating technique. The outer hoppers axe discharged first, followed by the inside hoppe:. Once the coal is charged, the lids are put in place and the lidman lutes the lids by hand which forms a seal around the lid. It is most important that the 1 ids be carefully luted and, if necessary, luted several times to prevent emissions from the oven.

Visual observations and NIOSH sampling results during the survey show top side emissions, including charging emissions, to be very low. The abatement equipment such as the modified larry car and the operating technique of stage charging appear to be very effective in minimizing charging emissions. Careful luting of the top side iids Eollowing coal charging appeared to eliminate lid leaks with one or two exceptions.

The meteorological conditions at the plant appeared to lower worker exposures to charging emissions. The wind carriec away much of the smoke and gases emanating from the coke oven battery.

A second coke oven plant produces blast furnacé coke for sale, and has an annual production capauity of 2 million tons of coke. The plant has three coke oven batteries. All the coke ovens are charged by larry car. The two nearer batteries, I and 2 , have a larry car equipped for stage charging and automatic lid opening, closing, and mudding. The automatic lid opening, closing, and mudiding device works well mechanically; however, the automatic mudder does not completely seal the lids, so automatic mudding must be followed by nand luting. The automatic lid closing and mudaing device benefits the lidman by eliminating most of the lid emissions prior to hand luting. Oven drafting ir accomplished by use of double collection 
mains. Goosenecks and standpipes are cleaned and maintained by decarbonization cycle, routine inspection, and cleaning 'y" hand. Twice per year, the goosenecks are hydraulically cisared with 4,000 to 10,000 psi pressure. The larry car on the older number 3 battexy has been retrofitted for stage charging tinrough three charging holes instead of the usual four. The larry car does not have a screw Eeeder or an automatic lid opener and mudder. Despite the use of the stage charging control technique, visible colored emissions were observed during charging on battery 3. The cause of the emissions appears to be inedequate oven drafting and leaks in the dropsleeve.

A third plant inspected is a full integrated steel plant with 8,000 employees, including 300 coke oven workers. The plant has seven coke oven batteries. Batteries 1 to 5 are 25 to 30 years old, while batteries 6 and 7 are approximately 20 years old. Each battery consists of approximately 45 coke ovens. Oven dimensions are 14 inches by 13 feet by 40 feet.

The coke ovens are charged by Larry cars designed for stage charging. Each larry car is equipped with stainless steel lined hoppers, vibrators, and poco sticks (to break the coal bridge that develops on hoppers). Oven drafting consists of aouble collection mains. Top side lids are hand luted. Standpipe and gooseneck are cleaned manually. The plant does not use high pressure water to clean goosenecks because of the safety problem in controling the direction of the water jets.

Visual observations showed emissicns from charging were very low. The larry cars with stage charging appeared to be well adaptea to the batteries. Stage charging at this plant appears to be an effective control technology for reducing charging emissions.

A fourth plant that was surveyed employed more than 8,000 workers of which 400 are coke oven workers. Two side-by-sicie batteries were observed. Oven aimensions of the two batteries are 18 inches wide, 11 feet high, and 38 feet long.

Coke oven charging consists of larry car. stage charging. The larry car is designed with stainless steel-lined hoppers: volumetric controls, air and sticks for breaking the coal arch, jumper pipes on the larry car, and drop sleeves around the discharge openings. The gooseneck is manually cleaned, and lids and standpipes are manualiy luted.

As a result of stage charging and adequate aspiration (drafting), charging enissions appeared very low on the two 
batteries. Again, larry car stage charging appears to be a satisfactory control method for charging enissions. It should be notec that, while jumper pipes may provide adequate aspiration, double collection mains are the preferable control technology.

Another plant obscrved produces foundry coke for sale. It employs approximately 150 workers. The batteries are Kopper's design. Coiring time is typically 27 to 30 hours, which is much longer than tise 16 to 20 hours typical for metallurgical coking.

Coke ovens are charged by larry car stage charging through five charging ports with 150 psi steam aspiration. The larry car is equipped with stainless steel hoppers, pneumatic vibrators, and drop boot sleeves. Gooseneck standpipes are inspected after each push by inserting a 7-inch diameter plate into the gooseneck pipe. The goosenecks are cleaned by using a preumatic chipping tool.

Coke oven charging methods at this plant difEer somewhat from charging systems previously discussed. There are five charging ports for each coke oven where normaliy there are three or four charging ports. Steam aspiration of 150 psi exceeds the pressure found in most coke oven orafting systems. Stage charging with 150 psi steam aspiration (with properly sized nozzle) may potentially improve control of charging emissions.

In addition to the larry car charging control systems observed in this study, there are a number of other united states and foreign control techniques for reducing charging emissions. For the most part, these controls have been tried and rejected or. are of recent development.

Larry mounted wet scrubbers have operated in japan, England, Germany, the Netherlands, and in America. In the larry mounted wet serubber, gases from charging are combusted and drawn through wet scrubbers. The scrubbed gases are exhausted by $f a n(s)$. There are two common types of gas scrubbers: Rotary and venturi-type (5).

Eattelle observed wet $\mathrm{scrubbers}$ at 12 different plants. None of the scrubber cars managed a completely smokeless charge. Many operators complained about the scrubber car and indicated it required extensive maintenance. Battelle summarized its findings regarding wet scrubber cars and made the following comments: "I) They are relatively costly, complex, and sensitive to adjustment, 2) scrubber cars create a substantial. probiem in the disposal of polluted exiaust waters, 3) overall operational history indicates progressively severe maintenance problems and 
increasing breakdown rates, and 4) a state-of-the-art wet scrubber in good condition and properly adjusted, operated in connection with strong aspiration, can eliminate all but a little of charging smoke about 90 percent of the time" (5).

"Sequential charging" iss an operating technique to control charging enissions. Sequential charging, as defined in the United States, refers to the discharge of coal from all larry car hoppers into the oven in the following manner: The outer hoppers, numbers 1 and 4 (for uvens with four lids), are discharged first, followed 9 to 12 seconds later by hopper number 2 and a few seconds later by hopper numbe: 3 . The essential difference between sequential and stage charging is that once sequential charging begins it must continue until all the hoppers are empty (5). U. S. Steel found sequential charging blocked the turnel head, allowing smoke to escape through dropsleeves and hoppers. It was concluded that sequential charging was an unsatisfactory method for controlling charging emissions $(6)$.

The American Iron and steel Institute and Environmental Protection Agency developed a larry car charging emission control method called the AISI/EPA charging system and tested it. at the Jones and Laughlin steel plant in pittsburgh. The system attempts to control emissions by closing off all gas escape routes, increasing injector steam pressure, and by collecting gases in a single collection main. Gas escape routes are the chuck doors, which are closed of by a seal around the leveler bar, and coal hoppers, which are sealed by a butterfly valve. The AISI/EPA charging system also has automatic lid lifters, a standpipe gooseneck cleaner, and a communication and sensing system(7).

As of 1975, the AISI/EPA charging system had been tested at $J$ and I steel (Fittsburgh), and was being added to two other American coke plants. Batteile investigators, based on observations in 1973, did not consider the AISI/EPA car as a completely satisfactory charging emission control technique(5).

A larry car charging system, similar to the AISI/EPA car, is the Still-ERIN system widely used in Germany. An American version of the Stili-ERIN car has been built at a new American coke oven plant. The American still-ERIN car is equipped with mating dropsleeves, slidegates, screw feeders, and automatic lid mechanism. The concept of the still-ERIN system is to closely fit the hopper extension (charging telescope) to the charging hole, control coal flow by an oscillating butterfly valve, close off hoppers before emissions escape, and steam aspirate gases into a single collection main. The American coke oven battery 
with modified Stili-ERIN car includes double collection malns to improve oven drafting.

Battelle ranked still-ERIN fourth as a control technology for charging emissions behind closed charging (pipeline or Redler conveyor), stagea charging, and the best jersions of vet scrubbing (5\%. Graham and Kirk found results, to date, on the still-ERiN car "not very encouraging" (8).

Fixed duct secondary collectors in conjunction with larry car wet scrubbers have been used extensively to control charging emissions in Japan. In the fixed-duct system, charging emissions are exhausted, through a larry car scrubier, then tr.rough a stationary collection main to a fixed scrubber, and then to a fan for discharge to the atmosphere (9). Above eash oven is a connection port to the stationary collection main. Battelle concluded the fixed duct secondary collector was not potentially effective, relative to incramental cost(5).

\section{PREHEATED COAL CHARGING SYSTEMS}

A pipeline charging system was observed at a fully integrated steel company employing 23,000 workers, including 1,300 coke oven workers. The plant has six coke oven batteries; however, only the one battery, with pipeline charging, was observed. Thie pipeline charging system (Coaltek System) feeảs preheated coal under pressure to the coke ovens $(10)$. The system is a closed system which should theoretically, eliminate charging emissions. The coaltek system allows the use of more plentiful but lower quality Illinois coals without sacrificing quality and reduces coking time. Major startup problems with the coaltek system included leaks and piugged distribution lines. Most of these startup problems have been solved but some remain.

More research is needed to evaluate the performance of the Coaltek system as a control technology for charging emissions. Such research could be done at one of the coke oven plants which have instalied the Coaltek systems. Semet-Solvay Division, Allied Chemical Corporation, Detroit, Michigan; Alabama By-products Corporation, Tarrant City, Alabama; Inland Steel Company, East Chicago, Indiana; and J and L Steel, Aliquippa, Pennsylvania, have craltek preheating and pipeline charging installations(11) (12).

The Bergbau-Forscheing Precarbon System, developed by Didier-Kellogg: is another method for charging preheated coal $\left(2000^{\circ}\right.$ ) to the coke oven. Like the coaltek System, the Bergbau-Forscheing system eliminates the larry car. Unlike the Coaltek System, the Bergbau-Forscheing System transports 
preheated coal from a weigh hopper to the ovens by a Redler-type conreyor and chuces connected to the charge holes. The system $\therefore s$ in the early stages of development and appears promising (8).

A third version of preheated coal charging is England's Simon-Carves (Simcar). The unit preheats wet coal to $2400 \mathrm{C}$ in two stages using a specially designed car for charging. Simcar was developed through research sponsored by British Steel. Coiporation; even so, British steel Corporation has deciced to use the coaltek system instead of simcar at two of its plants (13).

PUSHING EMISSIONS CONTROL TECHNOLOGY

Pushing emissions result when hot coke (carbonized coal) is farced out of the long narrow ccke oven into the quench (hot) car. Emissions continue as the quench car moves to the querich tower.

According to the 1970 Battelle study, pushing emissions were second to charging as the most serious source of emissions(14). Inproved charging controls have increased the relative seriousness of pushing emissions, especially emissions from "green" pushes. A "green" push is incompletely carbonized coke that produces a tremendous greenish-black emissions plume. Pushing emission controls have a two-fold purpose: 1) Ta reauce relatively low emissions from normal high quality coke and 2) to reduce serious emission resulting from a "green" push.

Pushing emission controls include:

Sheds
Canopy Hoods
PECT
Ericar
Fog Spray
The White Giant
(Der Weisse Riese)
Halcon (Interlake)
Osterfeld Car

\author{
Weirton (Koppers Car) \\ Envirotect. (Chemico) \\ Granite ity steel one \\ Spot Car \\ Mitsubishi Fixed Duct \\ Koppers Fixed Dust
}

Genoa-Corigliano

calderon super quencher

In this study, Nrosy investigators observed pushing control systems at the seven plants visited. Sheds were used at two plants. One plant installea a shed over the battery coke side primarily to prevert air poliution from pusing emissions anddoor leakage. The shed j.s approximately 40 feet high and is open to a height of 10 feet along the entire bottom. Pushing and door emissions rise up the side of the battery into a large duct at the top of the shed, and exhaust to the air cleaning 
system. The shed appears to slightly increase exposure of coke side workers (under shed), whil.e slightly reducing the exposure of top side workers. The shed was designed with open ends, partially open sides, and a high rate of exhaust ventilation. This design, along with strong ventilation, greatly reduces coal tar pitch volatile (CTPV) concentrations from the high levels that could easily occur under the shed. Data from the plant show the highest CTPV concentration under the shed was three times the standard of $0.150 \mathrm{mg} / \mathrm{m}^{3}$.

The shed at the second plant also encloses the battery coke side. This shed is 360 feet long with a volume under the shed of 200,000 cubic feet. Two 200,000 cfm fans exhaust air from the shed. The exhaust fans were down for repair during our visit, and a result we observed was poor visibility linder the shed and heavy fallout of particulate matter resulting from pushing the oven.

One coke producer tas developed a method for controlling pushing emissions called the pushing Emission Control Technology (PECT) system. It is designed primarily to control "green" pusties. PECT differs from a quench car or a one-spot hot car. Details of the PECT system are presently confidential, since attempts are being made to have PBCT patented. Observations by the NIOSH investigators showed PECT effectively controlled pushing emissions. According to a piant official, operator acceptance of the PECT is total. It appears the PECT system may also have cost advantages over other pushing emission control technologies.

The Ericar is a patented systern for controling pushing emissions. The Ericar is an ordinary quench car with a movable steel curtain that encloses the hot coke as it is pushed into the quench car. The hot coke gases exhaust through flexiole piping to a scrubber car that rides on $\vec{a}$ track behind the quench car. The scrubber cleans the hot gases before discharging them to the atmosphere. We observed that the Ericar effectively controlled "non-green" pushing emissions.

No special pushing emizajon controls are used at several coke oven plants visited. The hot coke is pushed into an ordinary quench car and quickly moved to the quench tower for quenching. Despite the lack of special pushing emission controls, the pushing emissions were slight at these plants. Data provided by cne plant with no special pushing control and our observations indicate that pushing emissions make a small contribution to overall worker exposure to CTPV.

A "fog spray" system for controlling pushing emissions vas observed at a coke oven plant producing merchant coke for sale. 
As coke is pushed into the quench car, the fog spray system is activated, and water is sprayed on the hot coke. The fog spray produced scme steam but no black smoke. "Ihe spray nozzles of tine fog spray system are located on the quench car, and the pump anä a 500-gallon water tank are located on the locomotive. The Eog spray system uses about 250 gallons of water per push. The coke oven manager explained the key to a successful fog spray system is the design and installation of the pumps and spray nozzles.

The literature contains a number of additiona? pushing emission control systems which are described below.

"Der Weisse Riese" (the White Giant; is a bench-mounted, self-contained hood for controlling pushing emissions. The hood covers the lot car during the entire push. The White Giart features a draft and scrubbing system without moving parts. A Battelle team was favorably imp:essed by the white Giant because of its good collection and scrubbing of emissions. The scrubbers produce a clean exhaust and do not simply dilute the emissions. The disadvantage of the White Giant is its large, heavy, ana costly design. The steaming and water supply system are difficult to construct and operate. There is also a problem with corrosion of the rotor venturis (5) (15).

Interlake, Inc. tested a protctype coke oven pushing emission control car in 1973-74. The Interlake (Halcon) car consists of three units: A 20-ton electric locomotive with an operator control panel; a 40-feet long quench car with a Eume capture hood; and a tra.ler control car with pumping, heating, cleaning, and demisting equipment.

The trailer car also contains a 2,400-gallor service water tank. The Halcon car operates by passing hot, pressurized water through jet-type scrubbers to clean the smoke and gases collected in the hooded quench car. The scrubbed gases pass through a demister and are emitted to he atmosphere(16).

As a result of tests conaucted in 1973, the prototype Halcon car was modified to include a canopy-type hood over the sintire width of the car. In addition, sheeting was hung along the battery side of the quench car parallel to the hood. The improved hood design, ajong with increased succion, has resulted in satisfactory performance of the emission control car and capture $c$ emission fumes. A remaining major disadvantage of the emission car is the likelihood of freezeup during winter operations (16).

The Osterfeld (or Firma Carl Stil1) emission control system consists of two cars: A hot coke transport car (container car) 
and a continuous wet quencher, The container car captures pollutants from the pustred coke and continuously cleans the thot coke as it is transported to the quenching station. The wet quencher graduall quenches the coke, thus eilminating any sudden plumes of steam and water vapor.

The container car is designed with a bin in the lower part of the car. The bin has a capacity for 33 short tons of coke. Above the bin is a space covered by a hood to contain emissions. In the hood is an opening to match the opering of the coke guice. As coke enters the container car, smoke and gases are exhausted to the wet scrubber. After the coke is pushed, a light door covers the hood opening where the coke entered. The container car then moves to the quencher area while discharging the coke to the continwous wet quencher. Both the container end wet quencher cars are planned for automatic operation, but, during testing, an operator was assigned to each $\operatorname{cor}(17)$.

Test results at the Osterfield plant in Germany show that pushing emissions are adequately scrubbed during normal operation; however, strongly "green pushes" cannot be statisfactorily cleaned. A 50 percent increase in scrubbing capacity was recommended for the container car. An interesting feature of the Osterfeld system is that, despite a lot of rough handling, the abrasion of the coke was minimal (17). According to Battelle investigators, the osterfeld car (stili) represents an advance in the state of the art for controlling pushing emissions (5).

National steel Corporation in Weirton, West Virginia, developed a one-spot hot car and continuous quencher. rt is similar in concept to the Interlake (Halcon) and Osterfeld systems. As coke is pusned into the weirton hot car; a stainless stee? curtain encloses the hot coke and gases. Pushing emissions are drafted through: a refractory-line duct to the gas cleaning system on a second railcar. Graham et al., in 1975, found the weirton (Kopper) systen to have excessive operation and

mainterance problems (8). 'iraubert of National steel stated in 1977, that for the most part, the enclosed (Weirton) quench car has been successeul, but the gas cleaning car would be more effective witì some design changes. One such change included is stainless steel piping to replace mild steel piping(18).

Chemico (Envirotech) has developed an enclosed quench car for controlling pushing emissions. In the Chemico system, hot coke is guided into the quench car and emissions are drawn through the hoo? into an atiached control car. The emission gases are 
scrubbed and discharged to the atmosphere as the hot car moves to the quench tower. Chemico system consists of a three-sided hood attached to the quench car and a wall attached to the coke guide that forms a fourth side. Two hot water scrubbers doaw the smoke from the open oven and the hood at rates up to 90,000 scfn: Chemico sold one of their hooded quench cars to $J$ and $L$ Steel in 1976 (19).

In an effort to develop a suitable enclosed pushing and quench system, Granite City Steel came up with their own one-spot enclosed coke pushing control system. The Granjte City system consists of a "coke guide" enclosure, a coke receiving car, and a connection between the coke guide enclosure and the coke receiver car. The coke guide has a telescoping hood which meets the movable hood section of the coke receiver car. The receiver car is an enclosed box-like structure, except for an opening for coke to enter and a connection to the gas cleaning car. Pushing emissions evacuated from the coke receiving car are cleaned by high energy variable throat venturi scrubbers located on the gas cleaning car. The Granite City gas cleaning car eliminates the locomotive from the pushing control system. According to Granite City researchers, field tests show the one-spot enclosed plishing control system is simple to operate and does not increase cycle time between pushes (20).

Mitsubishi Chemical Industries (MCI) Ltd., Tokyo, Japan, has developed a pushing control systern, the Mitsubishi-Amagaski-Shinwa smolseleas pushing technology. The system consists of a movable hood coveririg the quench car, fixed duct.s, and a wet scrubber and fan. The wet scrubber, fans, and water supply system axe stationary while the hood is attached to and moves with the coke guide. The hood connects with one of $a$ series of suction ducis located above each oven. As coke is pushed, emissions flow from the houd through the suction ducts to the wet scrubber and are discharged to the atmosphere. A critical feature of the MCI pushing emission control system (fixed duct) is a tight connection between the hood and the suction ducts. A poor connecticn results in the escape of almost ali pushing emissions to the atmosphere. According to Battelle, the successfully performing MCI system at the l'akogawa plant in Japan had drafts of 140,000 cfm.

MCI pushing emission control technology (fixed duct) eliminates the bench-mounted machinery for cleaning pushing emissions. Such extra machinery can lead to safety and structural problems on the battery. The MCI pushing control technology has been added to a nlimber of existing coke oven facilities in Japan (5) (15) (21). 
Koppers fixed duct pushing control technology is similar to the MCI. The Koppers sysiem consisis of a movable hood over the soke guide and part of the quench car, a fixed duct along and parallel to the battery, and gas cleaning equipment. The Koppers system differs from MCI in the type of hood and in fine points of connecting the hood to the fixed ducts. A Kopper Eixed duct pushing control system has been installed at ford's Dearborn coke oven plant. similar to MCI system, the Kopper system at Ford will $r \in q u i r e$ an estimated draft of $140,000 \mathrm{cfm}$ for its tall, new battery. However, actual draft requirements depend on the type of scrubbing system used(8).

Some adaitional pushing control systems of lesser. interest are the Genuam Corigiiano designed by Heinrich Koppers of Germany (8) and the Calderon Super Quencher in the United States(22).

Pushing emissions can sometimes be controlleu by zepairing ovens and by improving work practices. Emissions can be reduced by repairing end flues, decreasing coal volumes, and slowing the coking rate. Poor operation such as overflowing ovens or improper coal blending can also increase pushing emissions(23).

In newer, well-operated and maintained coke oven plants, "green pushes" may be relatively rare. In such cases it may be best to ossign pushing emission controls for typical emissions rather than for an occasional "green push."

\section{CONTROLS FCR CONTINUOUS EMISSIONS}

\section{TOP SIDE LEAKS}

Top side leaks come primarily from charging hole lias, standpipes, and goosenecks. Leaks from charging hole lids range from short wisps to continuous leaks. Generally, charging hole lids are hand itud immediately after the coal is charged. standpipe leaks are often continuous and are controlled by hand Iuting, but, as the standpipe sheet metal deteriorates over the years, hand luting is no longer sufficient to stop leaks. Eventiall.y the top side steel must be replaced. Gooseneck leaks are continuous and are controlled by hand luting.

Top side charging hole lids were generally sealed by hand luting. It was observed that emissions from the iids $r$ anged from negligible on one battery to several iid leaks on the worst baitery. Enforced work practices appeared to be the key to minimizing leaks from charging hole lids. A second factor is the type of coke produced since the plant with the fewest top side leaks produced fcunciry coke. 
One plant the NIOSH team observed lises automatic mudding equipment attached to the larry car to seal charging hole lids. The automatic mudding machine seals most of the groove around the Iid; however, it is still necessary to manually lute the small gaps left by the automatic mudding machine. The automatic mudāer provides a major benefitt in that j.t reduces the lidman's exposure by partially sealiny the lid before the liaman has to hand lute it.

Where top side steel is in good condition, frequent inspecticn and hand luting will satisfactorily control standpipe dnd gooseneck leaks. If top side steel is in poor condition, hand luting will most likely be inadequate, and the top side steel must be replaced. At ore plant with side-by-side batteries, a battery with relatively new top side steel (less than 10 years old) had very few top side leaks, while several older batteries (20 to 30 years old) had numerous standpipe and gooseneck leaks. Tt was apparent that the aging and deterjoration of the top side steel had a major effect on the top side emissions.

Significant top side emissions can result where charging hole lids fail to seal properly because the lids have been distorted by high temperature. In such cases, the lids must be replaced. Leaks can occur when lids are not regularly cleaned and the jid fails to seal properly (9) (23).

Because of the impostance of work practices in controlling top side continuous emissions, one coke oven plant has developed a system where inspectors regularly check the coke oven battery cor visible emissions. The inspectors are in a separate branch from the regular operating crew to increase their objectivity.

DOOR LEAKS

Because of improved charging methods and better control of pushed emissions, more and more attention has been directed to controlling door leaks. From the standpoint of worker exposure, door leaks are of primary importance. Door leaks from a sirigle oven can last an hour or two following the charge, or can last through the entire coking period up to 16 hours. Door emissions rise up and contaminate battery top side workers as well as the coke and push side workers. Most coke oven batteries have metal-to-metal self-sealing doors on the coke side and the push side. In general, leaiage from metal-to-metal doors is a serious enission problem at most coke oven plants. At several plants, sheds are used to prevent door emissions from entering the atmosphere. A shed, even when well 
ventilated, presents two problems to the worker: 1) The shed encloses the door emissions and may increase worker exposure and 2) the shed hides the emissions so there is a tendency to delay repairs to leaky doors. Some workers under the shed have protection of the filtered air conditioned cab; however, coke side benchman must work under the shed outside the air conditioned cab. Despite a well-ventilated shed, foor emissions should be reduced to the maximum extent possible to protect the coke side benchman. The shed does have the apparent advantage of reducing the exposure of top side workers to door emissions.

As discussed earlier, one of the plants observed in this study has a series of side-by-side batteries of various ages. All the batteries have 4-meter, metal-to-metal self-sealing doors. The older batteries (25 to 35 years old) have extensive door leaks while the newer batteries (less than 20 years old) typically have few door leaks. One 30-year old battery, recently rebuilt, including the oven ends, had very few door leaks. The age of the ovens, particularly the oven ends and the age of the doors, appear to be the major factor in door emissions. Along with the age factor, wear and tear caused by excessive heat stresses accelerates door emission problems. Operating errors are often the cause of excessive heat stress.

Large, 6-meter metal-to-metal doors are found more and mice at coke oven plants. At one plant we observed several 6 -meter doors which ieaked severely due to warpage. As industry converts to l.arger 6-meter, metal-to-metal doors the problem of door leakage will increase. For this reason, additional research is recommended to improve the design of the larger doors to minimize warpage and reduce emissions. One plart we surveyed has tested Japanese IKIO doors and the Caulderon automatic mudaing technique for sealing doors. The IKIO doors appear promising. Tests on the Calderon technique show problems with pressurizing the sealing material for injection irito the groove between the door and door jambs (see page 36).

Normally: chuck doors--small doors that open for the leveler bar--are closed by the door machine; however, at one plant a wrench is used to open and close the chuck door. This practice ensures a tighter chuck door seal and thereby reduces door emissions.

Another method available for controlling hoor emissions is to hand lute coke oven doors. At one plant with hand luted doors, we observed very few door leaks and a very clean plant cverall. The plant manager stated this was due to careful luting of doors and strictly enforced work practices. The door emissions may have been easier to control becalise foundry coke was produced. 
Guillotine doors are rarely found at coke oven plants although they have certain advantages. The doors can be raised or lowered to any desired height above the bench. This allows the benchman to raise the door 1 or 2 feet, shovel loose coal into the oven, and then lower and close the oven door. Loose, smokey coal can be cleaned up with only slight emissions from the oven. The disadvantage of guillotine doors $i$ is that they require hand luting, and it is impractical to add guillotine doors to existing coke oven batteries.

Push side controls used to control door emissions include a shroud over the leveler bar and an exhaust hood above each push side door. The shroud captures the coal dust the leveler bar picks up during withdrawal from the oven. The exhaust hood is used to capture door emissions on the push side. The operator looks for door leaks and, when he spots one, he activates the exhaust hood above that particular coke oven door. From the hood, the emissions are exhausted by a central fan to the air. pollution equipment. Up to four hoods can be exhausted simultaneously, Because installation was not complete, we were unable to observe the exhaust hood systein during our visit. It is recommended that this exhaust hoo $\overrightarrow{0}$ door emission control system be evaluated further.

An incentive program for controlling coke oven door emissions is being used at one steel plant. According to the coke oven plant manager, the incentive program has had some limited success in reducing emissions. Because of the possibility that incentive programs may lower door emissions, it is recommended that results of the incentive program be documented.

Graham and Kirk believe that good operation and maintenance practices are the key to controliing coke oven door emissions. self-sealing doors and frames must be properly scraped and cleaned. Improperly cleaned doors will end up leaking. For new, taller ovens, door and frame-cleaning machines are recommended (8).

Jones and Laughlin steel Corporation has very recently developed an improved metal-to-metal self-sealing door. The improved door design should reduce bowing and hourglassing. Bow is defined as "curvature of the jamb into or out of the vertical plare due to thermal and mechanical forces." Hourglassing is "a tendency for the iong sides of a jamb to close together due to temperature differentials." Excessive bowing and hourglassing prevent adequate door sealing and must be kept within tolerable limits (24). 
Barchfeld et al. state that the improved $J$ and $L$ designed door minimizes both bowing and hourglassing. The improved design consists of a vented coke oven door plug, spring loaded knife-eage s-seal using a NiCuTi material, a special seal pan to hold the S-type seal, door/seal stops to control door deflection, guides to position the door for repeatabla seal positioning on the jamb, and a removable seal to reduce door/seal replacement costs. As a result of 4 months of tests, door emissions were low enough to meet a local government requirement that no more than 10 percent of the coke oven doors leak (24).

$J$ and $L$ is also testing a soft seal to be used as rasket material for the end doors. Two materials, graphite fiker and asbestos fiber, have been tested. Early results show that the graphite began to fail after several months of use. The asbestos gasket continues to function well over $a$ much longer period $(24)$.

Arother technique to reduce emissions from self-sealing doors was developed by Calderon Automation, Inc. With this technique, a material with bloating properties is injected into a groove between the door and the coor jamb. A sealing ring is constructed inside along the perimeter of the door and forms a groove that receives the new sealing material. This groove takes the place of the sealing edge on typical metal-to-metal doors. The sealing material must be cleaned off after every push. Fresh sealing material is then injected before the door is closied. The Calderon sealing technique can be applied to chuck cloors as well as 6-meter doors. Injecting sealing material in smaller chuck doors is fairly simple, requiring only one injection port; however, larger doors require at least four injection ports (.22).

Operating techniques can also be used to help control door enissions. One technique considered is to decrease oven back pressure; tut, if improperly applied, this technique can damage oven brickwork (9) (23). Coke oven plants can further improve door emissions' control by having backup door machine equipment and spare parts on hand to minimize interruptions to operations!9) (15).

Battelle investigators summarized door emission control technology in stating door sealing technology and practice is still more art than science" heavily dependenc on the attitude of the bencis crew and ripe for intensive studies and experiments. Battelle also stated that firm conclusions regarding control technology for door leakage could not be made (5). 
Since the Battelle recommendations, EPA has funded several research studies on control technology for coke oven door emissions. A July 1975 EPA Report, "study of Concepts for Minimizing Emission from Coke Oven Door Seals" (EPA

650/2/75/064), describas door sealing techniques available. EPA has recently funded a study to review control technology for coke oven doors (25).

\section{WORKER ENVIRONMENT}

Coke oven worker exposure can be reduced by providing filtered air cabs, standby pulpits, and lunchrooms. In this stuky, we observed operators of larry cars equipped with an enclosed air conditioned cab, coke guide/door machine operators under a shed in enclosed air conditioned cabs, quench car operators under a shed in an enclosed air conditioned cab, and push car oferators in enclosed air conditioned cabs were observed. It was apparent that filtered air cabs were suitable for workers who could stay inside the cabs. It was observed that the pusherman and the coke side door cleaner did stay in the cal while the larry car operator frequently left his cab to perform duties such as operating the mechanical gooseneck cleaners. The effectiveness of erclosed air conditioned cabs depends primarily on how muei time the operator spends in the cab. Before selecting a filtered air cab as a control, the percentage of time the operator spencs in the cab should be quantified. We also observed an enclosed filtered air conditioned lunchroom near the battery at one plant. The Iunchroom uses air filters made by "James Campbell smith." According to tests at this plant, the best filters for coke oven application are made by two companies: "James Campbell Smith" and "Iintern."

The Mine Satety Appliance (MSA) Research Center, under contract to NIOSH, has tested a Eiltered air (air purifying) unit in a

OFFICE FOOTNOTE: Information presented at Air Pollution Control Association Conference on Control of Air Emissions from Coke: Plants, April 17-19, 1979, pittsburgh, Pennsylvania:

1. Door extractors have bcen found to damage the knife edge resulting in extensive door emissions;

2. NiCuTi material is superior to stainzess steel as a knife eơge material; and

3. Reducing the diameter of stanapipe caps about 3/4-inch results in a betier seal between the cap and the standpipe casting. 
coke oven atmosphere. The unit consists of an MSA ultra aire HEPA Eilter, a catalytic oxidizer, and a charcoal bed. The Eilter was tested by mounting it in a larry car cab. Results showed the air purifying unit significantly reduced co, total hydrocarbor, total sulfur, total particulate, and NO/NO . $^{\mathrm{MSA}}$ recommended the elimination of the catalyst bed because co levels on the coke oven were already low. MSA also recommended that the filter be scaled up to full size and tested over a period of approximately 1 year (26) .

Enclosed filtered air cabs, standby pulpits, and lunchrooms can be effective controls for reducing worker exposure to coke oven emissions. But to be effective, the enclosed rooms or cabs should be tightily constructed and have properly designed and installed air filters. Finally, enclosed filtered air rooms and rabs are effective only if the worker stays in the room or cab. Filtered air. lunchrooms may not be effective where smoking is permitted in the lunchroom. A research project to evaluate Eilters for enclosed filtered air rooms in the coke oven environment is recommended.

\section{CONCLUSIONS AND RECOMMENDATIONS}

\section{CONCLUSIONS}

1. In oxder of priority, major sources of coke oven emission sources are (1) doors, (2) top side leaks, (3) charging emissions, (4) pushing emissions, and (5) coal shoveling practices.

2. A major technological breakthrough is required to significantly improve emissions control of state of the art larry car charging technology.

3. The advantages of pipeline charging are reduced top side emissions and removal of the larry car operator and lidman from the exposure area on the battery top side. Disadvantages include start up problems, high capital investment, and lack of data on the effect of pipeline charging on the exposure of the benchman and maintenance workers.

4. For new coke oven batterles with even heating $f J$ ues, adequare coking time, and consistent cycling, "green" pushes should be rare and the overall impact of pushing emissions on worker exposure should be relatively smali.

5. Top side leaks from charging hole lids, standpipes, and goosenecks are best controlled by good work practices such as careful hand luting. Automatic mudding techniques are available 
but must be followed by hand luting. Inventive programs to encourage good work practices have had some limited succes: . Major standpipe and gooseneck leaks should be controlled by replacing top side steel.

6. Sheds over the battexy coke side have the apparent advantage of reducing top side vorker exposure and the apparent disadvantage of increasing coke side worker exposure, especially to the benctiman.

7. The age of the oven ends and doors along with the wear and tear caused by excessive heat stress is the major cause of emissions from state-of-the-art metal-to-metal self-sealing doors. The taller coke oven doors are susceptible to greater warpage and thus greater emissions.

8. The effectiveness of control technology will vary from one coke oven battery to another. The type of battery, meteorology, battery age, and environmental goals must be considered before recommending a particular control. Meteorological conditions such as wind speed and direction greatly affect environmental concertrations on the battery.

\section{RECOMMENDATIONS}

1. Coke oven emission control technology research should emphasize contrcling duor emissions. EPA has recently funded a study to improve self-sealing doors to control door enissiuns. Research should be expanded to include luted doors, guillotine doors, and forejgn coke oven door technology.

2. Research is needed to evaiuate techniques for reducing warpage in the large, 5 -meter metal-to-metal self-sealing joors. ivew door technology such as Japanese IKIO doors and new typos of gaskets and sealing material should be employed as doors are reconstructed.

3. Well-ventilated sheds appear to increase exposure of workers under the shed. The evaluation of a well designed and well ventilated shed is needed to determine if and to what extent sheds increase worker exposure. New coke side sheds shoula not be built until more data developed on the exposure of the coke side benchman working under the shed.

4. The effectiveness of exhaust hood use above push side doors should be evaluated.

5. The unique stage charging and aspiration system (discussed on page 15-16) appears to be an improved method of controlling charging emissions. This system should be evaluated further. 
6. Preheated coal charging sysiem (both pipeline and. (both pipeline and chain conveyor) reduces overall worker exposure because it eliminates the larryman and lidman. Therefore, preheated coal charging is recommended for new coke oven batteries provided: (I) The system does not increase the exposure of other workers and (2) startup problems cain be minimized.

7. The percentage of coke over, worker exposure due to pushing emissions should be determined and the results usied to developpriorities for application of coke oven control technology.

8. Researoh is needed to determine criteria for filter media used in lunchroom' standby pulpits, larry cars, and pusher and door machine cabs.

9. A time study to determine the percentage of time the larry car operator spends in/out of the larry car shoulu he yerformed at several coke oven plants.

10. Meteorological conditions should be considered when evaluating the effectiveness of emission control methods.

11. Graham and Kirk(7) suggest the gradual development and application of control technology has benefited the coking industry in the United Kingdom. We feel this approach is appropriate for development of coke oven control technology in the United States.

12. In coke oven emission control technology research, EPA should consider the effect of control technology on worker exposure.

\section{REFERENCES}

1. Lloyd, J.W., 1971. Long-term Morta]ity study of Steelworkers V.--Respiratory Cancer in Coke Plant Workers. J. Oscup Med. 13:53-68.

2. Redmond, C.K., A. Ciocco, J.W. Lloyd, and H.W. Rush. 1972. Long-term Mortality study of Steelworker--VI. Mortality from Majignant Neoplasms Among Coke Oven Workers. J. Occup Med $14: 621-9$.

3. Making, Shaping and mreating of Steel. 1971. United States Steel Corporation, pittsburg, pp 1420.

4. Exposure to Coke Oven Emissions. 1976. OsHA/DOL. Federal Register. Friday, October 22:4I(206): pp 46742-90. 
5. Barnes, T.M., H. W. Lownie, Jr., aná J. Varga. 1975. Control of Coke Qven Emissions. Ironmaking and Steelmaking (Quarterly). $2(3)$ : pp 157-87.

6. Munson, J.G., Jr. 1974. Stage Charging Reduces Air

Emissions. Enviro. Sci. and Technol. December 8(13):1062-4.

7. Kertcher, L.F. and B. Lineky. 1974. Economics or coke Oven Charging Controls. Journal of the Air Pollut. Control Assoc. August 24 (8): pp 765-71.

8. Graham, J.F. and B.P. Kirk. 1975. Problems of Coke Oven Air Pollution Control. Engineering Aspects of Pollution Control. Met. Ind. Engr. 174:pp 82-100.

9. Voelker, F.C. 1975. A Contemporary Survey of Coke Oven Air Irmissions Abatement. Iron and Stee]. Eng. February:52:pp 57-64.

10. Inland Steel. 1974. Congressional staff Tour. Indiana Harbor Works. November.

11. Davis, R.F., Jr. 1976. Coalteck system-Pipeline Charging Coke Ovens. Ironmaking Proc. Metal soc. AIME. (Am. Inst. Eor Mech. Engin.) 35: Pp 479-86.

12. Improving Coke Oven Operation with Pipeline Charging of Preheated Coal. 1976. Ind. Heat. June:43: fp 8-14.

13. Coke Oven Controls: Complex, Costly and Controversial. 1975. Chem. Week. November 11: II 7(22):28-9.

14. Plaks, N. 1974, The EPA Program of $R$ \& D for the control of Cokemaking Emissions. Ironmaking Proc. Metal Soc. AIME. 33: pp 109-20.

15. Standidge, J.A. 1975. Collection of Emissions from a Coke Oven proc. 22nd Ontario Industrial Waste Conference. June: $22: 177-86$.

16. Rodwick, T.E. 1975. Start Up and Testing of Coke Oven Emission Control Car. Ironmaking Froc. Metall. Soc. AIME. $34: 235-41$.

17. Price, J.Ǵ, T.A. Berg, and J. Siratman. 1974. Coke Oven Pushing Emission Control and Continuous Wet Coke Quenching. Ironmaking Eroc. Metall. Soc. AIME. 33:220-32.

18. Traubert, R.M. 1977. Weirton steel Div.--Brown's Island Coke plant. Iron and steel Enq. $54(1): 61-4$. 
19. Enclosed Coke Quench Cars Gain Ground As Method of Clearing Oven Push Emissons. 1976. 33 Magazine. October 14(10):pp 38-40.

20. Burroughs, J.D., J. G. Manda, and D.F. Cairns. 1976. Application of Enclosed Coke Pushing Emission Controls at Granite City Steel. Proc. of the Air Pollution Control Assoc. Portland, Oregon, Jure:69(76-124): pp 1-10.

21. Kitasaka, M. 1973. Iitsubishi Smokeiess Operation Technology. Ironmaking Proc. AIME. 32:95-108.

22. Calderon, A. 1977. Controlling Emissions from Coke Ovens. Iron and Steel Eng. 54(8):42-6.

23. Edgar, W.D. and J.M. Mullex, 1973. The status of Coke Oven pollution Control. Ironmaking Proc. Metall. Soc. AIME. 32: 76-84.

24. Barchfeld, F.J., I. Gerding, and J.M. Stall. 1978, New Developments of $J$ and $\mathcal{L}$ Drasticaljy Cut Coke Oven Door

Emissions. Metal Producing. May: 15(5):43-6.

25. Personal Communications. EPA. July 28.

26. Rodgers, S.J. and F. Roehlich. 1971. Evaluation of Air Purifying Device in a Coke Cven Atmosphere. NIOSH. MSA Research Corporation, Evans City, Pennsylvania. HSM-99-73-51, November 15: 19 pages. 